\title{
KREATIVITAS PENGEMBANGAN MEDIA LAYANAN BK DITINJAU DARI KESIAPAN BELAJAR PADA MAHASISWA PROGRAM STUDI BIMBINGAN DAN KONSELING IKIP PGRI MADIUN
}

\author{
Tyas Martika Anggriana *)
}

\begin{abstract}
Abstrak
Keberhasilan mahasiswa untuk menyelesaikan beban kurikuler adalah suatu hal yang penting. Pada mahasiswa program studi bimbingan dan konseling terdapat mata kuliah yang mewajibkan mahasiswa untuk melakukan praktik layanan bimbingan dan konseling dalam format klasikal, kelompok dan individual. Guna menarik minat konseli ketika mahasiswa yang sedang melakukan praktik melaksanakan layanan, maka mahasiswa harus mampu mengembangkan kreatifitasnya untuk mengembangkan media, yaitu media bimbingan dan konseling.

Penelitian ini bertujuan untuk mengetahui hubungan kesiapan belajar dengan kreatifitas pengembangan media layanan bimbingan dan konseling. Subjek penelitian adalah mahasiswa program studi bimbingan dan konseling IKIP PGRI MADIUN semester 5 tahun akademik 2014/2015 yang sedang menempuh mata kuliah PPL BK Mikro. Pengambilan sampel dilakukan secara random sehingga diperoleh sampel sebanyak 92 mahasiswa, dari total populasi 125 mahasiswa. Analisis data penelitian dilakukan dengan uji korelasi product moment.

Berdasarkan uji korelasi diperoleh koefisien korelasi sebesar 0,253 dengan taraf signifikansi 0,015 ( $\mathrm{p}<0,05$; signifikan). Hal ini menunjukkan ada hubungan positif yang signifikan antara kesiapan belajar dengan kreativitas pengembangan media layanan bimbingan dan konseling. Guna meningkatkan kreativitas pengembangan media bimbingan dan konseling pada mahasiswa maka mahasiswa perlu didorong untuk meningkatkan kesiapan belajarnya, dengan cara menyiapkan perangkat belajar sebelum proses pembelajaran dimulai.
\end{abstract}

Kata kunci: kesiapan belajar, kreativitas, media BK

* Tyas Martika Anggriana adalah Dosen Program Studi Bimbingan dan Konseling Fakultas Ilmu Pendidikan IKIP PGRI MADIUN.

Counsellia: Gunal Bimbingan dan Konseling 


\section{Pendahuluan}

Keberhasilan mahasiswa untuk menyelesaikan beban kurikuler adalah suatu hal yang penting. Mahasiswa harus menguasai semua materi pokok, melakukan latihan berbagai macam keterampilan, serta mengerjakan berbagai tugas sehingga memungkinkan mahasiswa menguasai seluruh materi pokok pada mata kuliah yang ditempuh. Mahasiswa kadang dihadapkan dengan tugas yang harus diselesaikan dengan baik sesuai dengan indikator penilaian yang ditetapkan oleh dosen pengampu. Setiap mata kuliah memiliki karakteristiknya masing-masing sehingga menuntut mahasiswa mampu menguasai proses penyelesaian tugas sesuai dengan karakteristik mata kuliah tersebut.

Pada mahasiswa program studi bimbingan dan konseling terdapat mata kuliah yang mewajibkan mahasiswa untuk melakukan praktik layanan bimbingan dan konseling dalam format klasikal, kelompok dan individual. Jenis layanan bimbingan dan konseling yang dilakukan dalam format klasikal contohnya adalah layanan informasi, layanan orientasi, dan layanan penguasaan konten. Jenis layanan yang dilakukan dalam format kelompok diantaranya adalah layanan bimbingan kelompok.

Jenis-jenis layanan tersebut memungkinkan mahasiswa untuk melakukan penyampaian materi baik di depan kelas maupun di depan kelompok. Guna menarik minat konseli ketika mahasiswa yang sedang melakukan praktik melaksanakan layanan, maka mahasiswa harus mampu mengembangkan kreatifitasnya untuk mengembangkan media, yaitu media bimbingan dan konseling. Media bimbingan dan konseling adalah media yang digunakan dalam kegiatan layanan bimbingan dan konseling.

Media bimbingan dan konseling adalah suatu peralatan baik berupa perangkat lunak maupun perangkat keras yang berfungsi sebagai alat bantu dalam kegiatan bimbingan dan konseling. Media bimbingan dan konseling juga dapat diartikan segala sesuatu yang digunakan menyalurkan pesan atau informasi dari pembimbing kepada siswa yang dapat merangsang pikiran, perasaan, perhatian, dan minat sehingga siswa akan mengalami perubahan perilaku, sikap dan perbuatan ke arah yang lebih baik (Sujiono, 2005).

Counsellia: Imnal Bimbingan dan Konseling 
Arsyad (2011) mengemukakan ciri-ciri umum yang terkandung dalam pengertian media adalah bahwa (1) media memiliki pengertian fisik (hardware), yaitu suatu benda yang dapat dilihat, didengar atau diraba panca indera; (2) media memiliki pengertian non fisik (software), yaitu kandungan pesan yang terdapat dalam perangkat keras yang merupakan isi yang ingin disampaikan kepada siswa; (3) penekanan media terdapat pada visual dan audio; (4) media merupakan alat bantu pada proses belajar baik di dalam kelas maupun di luar kelas; (5) digunakan dalam rangka komunikasi dan interaksi pembimbing dan siswa dalam proses layanan; (6) dapat digunakan secara massal (misalnya: radio, televisi), kelompok besar dan kelompok kecil (misalnya: film, slide, video), atau perorangan (misalnya: komputer, modul, radio tape, video recorder).

Berdasarkan pada uraian tersebut dapat disimpulkan bahwa penggunaan media dalam layanan bimbingan dan konseling membantu efektifitas penyampaian layanan. Kegunaan penggunaan media dalam layanan bimbingan dan konseling adalah memperjelas penyajian pesan atau informasi agar tidak verbalistis, mengatasi keterbatasan ruang, merubah perilaku dari yang tidak diinginkan menjadi sesuai yang diinginkan, dan menyamakan persepsi antara pembimbing dengan individu yang dibimbing. Sudjana \& Rivai (dalam Arsyad, 2011) mengemukaan manfaat penggunaan media adalah (1) proses pemberian layanan akan lebih menarik perhatian siswa sehingga dapat menumbuhkan motivasi belajar; (2) materi layanan akan lebih jelas maknanya sehingga dapat lebih dipahami oleh siswa dan memungkinkannya menguasai dan mencapai tujuan layanan; (3) metode penyampaian materi atau pemberian layanan akan lebih bervariasi, tidak semata-mata komunikasi verbal melalui penuturan kata-kata oleh guru, sehingga siswa tidak bosandan guru tidak kehabisan tenaga; (4) dalam proses pemberian layanan siswa dapat melakukan kegiatan mengamati, melakukan, mendemostrasikan, memerankan, dll, tidak hanya mendengarkan.

Beberapa jenis media yang dapat digunakan sebagai alat bantu dalam penyampaian informasi dalam layanan bimbingan dan konseling adalah media auditif (radio, tape), media visual (gambar, foto) dan media audio-visual (film bersuara). Secara lebih lengkap Leshin, Pollock \& Reigeluth (Arsyad, 2011) 
mengklasifikasikan media ke dalam lima kelompok, yaitu (1) media berbasis manusia, misalnya: guru, instruktur, tutor, main-peran, kegiatan kelompok, fieldtrip; (2) media berbasis cetak, misalnya: buku, workbook, penuntun; (3) media berbasis visual, misalnya: bagan, grafik, gambar, slide; (4) media berbasis audiovisual, misalnya: video, film, program slide-tape; (5) media berbasis komputer, misalnya: pengajaran berbantuan komputer, interaktif video.

Berbagai macam media tersebut dapat dipilih oleh mahasiswa sebagai alat bantu penyampaian materi dalam praktik layanan bimbingan dan konseling. Dalam penerapannya dibutuhkan kreatifitas dari mahasiswa yang bersangkutan. Usaha pengembangan kreativitas mahasiswa adalah suatu hal yang penting karena kreativitas mahasiswa masih belum berkembang secara optimal. Hal ini dapat diketahui dari sikap mahasiswa yang merasa keberatan ketika diberikan tugas untuk mengembangkan materi layanan bimbingan dan konseling berbantuan media. Sebagian besar mahasiswa masih menggunakan metode penyampaian materi secara konvensional melalui ceramah. Jika didorong untuk mengembangkan materi berbantuan media, mahasiswa hanya memilih untuk menggunakan slide. Tampilan slide yang disusun juga masih monoton dan penuh dengan tulisan tanpa disertai gambar. Kreatifitas mahasiswa untuk menggunakan media lain seperti main-peran, film, atau video masih belum optimal.

Kreativitas adalah kemampuan seseorang untuk menciptakan sesuatu hal yang baru dan atau memodifikasi karya yang sudah ada menjadi sebuah karya baru yang lebih bermakna. Suharnan (2011) mengatakan jika dikaitkan dengan kemampuan seseorang, kreativitas sering disebut sebagai daya-cipta, misalnya mengarang lagu, membuat lukisan, menciptakan produk baru, dan menyusun teori baru.

Ormrod (2009) menyatakan bahwa individu yang kreatif memiliki karakteristik menafsirkan masalah dan situasi secara fleksibel, memiliki banyak informasi yang relevan dengan suatu tugas, mengombinasikan informasi dan ideide yang ada dengan cara-cara yang baru, mengevaluasi pencapaian diri menurut standar yang tinggi, dan memiliki gairah dan karenanya menginvestasikan banyak waktu dan usaha dalam apa saja yang sedang mereka kerjakan. 
Terdapat banyak faktor yang mempengaruhi kreativitas mahasiswa. Munandar (2009) menyebutkan terdapat dua faktor yang dapat mempengaruhi kreativitas, yaitu dorongan dari diri sendiri dan dorongan dari lingkungan. Dorongan dari diri sendiri identik dengan konsep hubungan kreativitas dan aktualisasi diri. Rogers (Munandar, 2009) mengatakan bahwa sumber dari kreativitas adalah kecenderungan untuk mengaktualisasikan diri, mewujudkan potensi, dorongan untuk berkembang menjadi matang, kecenderungan untuk mengekspresikan dan mengaktifkan semua kemampuan organisme. Sedangkan dorongan dari lingkungan muncul dari keluarga, sekolah dan masyarakat.

Faktor pendorong kreatifitas yang berasal dari diri sendiri, diantaranya terkait dengan kesiapan belajar mahasiswa. Kesiapan belajar, baik itu kesiapan fisik maupun psikologis merupakan kondisi awal suatu kegiatan belajar (Darsono, 2000). Menurut Djamarah dan Zain (2006) kesiapan untuk belajar merupakan kondisi diri yang telah dipersiapkan untuk melakukan suatu kegiatan.

Slameto (2003) menyebutkan kondisi kesiapan mencakup 3 aspek, yaitu (a) Kondisi fisik, mental dan emosional, (b) Kebutuhan-kebutuhan, motif dan tujuan, (c) Ketrampilan, pengetahuan dan pengertian yang lain yang telah dipelajari. Dengan adanya kesiapan belajar maka akan mendorong mahasiswa lebih mencurahkan perhatiannya pada hal-hal yang sedang dipelajari. Pada proses belajar, kesiapan dapat mendorong mahasiswa untuk belajar secara aktif dan penuh semangat. Belajar dengan penuh kesiapan akan memberikan hasil yang memuaskan, tetapi sebaliknya belajar tanpa kesiapan memungkinkan hasil yang dicapai kurang memuaskan.

Hal tersebut sejalan dengan pendapat Darsono (2002) yang mengungkapkan prinsip-prinsip belajar meliputi hal-hal berikut:

1. Kesiapan belajar. Kesiapan baik fisik maupun psikologis merupakan kondisi awal suatu kegiatan belajar. Kondisi fisik dan psikologis yang kurang baik akan mempengaruhi hal-hal lain yang dibutuhkan untuk kelancaran belajar.

2. Perhatian. Sebagai suatu aktivitas yang kompleks, belajar sangat membutuhkan perhatian dari peserta didik. Perhatian pada peserta didik pada umumnya tidak timbul dengan sendirinya. Oleh karena itu, guru harus mengetahui kiat menarik 
perhatian peserta didik pada saat awal dan selama proses pembelajaran berlangsung.

3. Motivasi. Motif adalah kekuatan internal yang mendorong seseorang untuk melakukan kegiatan tertentu untuk mencapai tujuan (disposisi internal). Motivasi adalah motif yang sudah menjadi aktif, saat seseorang melakukan suatu aktifitas.

4. Keaktifan peserta didik. Dengan bantun guru peserta didik harus mampu mencari, menemukan dan menggunakan pengetahuan yang dimilikinya. Peserta didik harus dipandang sebagai mahluk yang dapat diajar dan mampu belajar, sehingga keaktifan peserta didik betul-betul terwujud.

5. Pengalaman sendiri. Peserta didik akan lebih cepat memahami dan memperoleh hasil belajar yang lebih baik ketika mengalami dan melakukan sendiri. Oleh karena itu guru harus melakukan pembelajaran yang memungkinkan peserta didik mengalami sendiri.

6. Pengulangan. Peserta didik perlu membaca, berpikir, mengingat dan latihan untuk mempelajari materi sampai pada tahap insight. Dengan latihan berarti peserta didik mengulang-ulang materi yang dipelajari sehingga materi tersebut makin mudah diingat. Dengan melakukan pengulangan, tanggapan terhadap materi semakin segar dalam pikiran peserta didik, sehingga semakin mudah direproduksi.

7. Materi pelajaran yang menantang. Rasa ingin tahu peserta didik (curiousity) terhadap suatu persoalan sangat mempengaruhi keberhasilan belajar. Dengan sikap seperti ini motivasi peserta didik akan meningkat. Curiosity ini timbul bila materi pelajaran yang dihadapinya bersifat menantang atau problematis. Untuk itu, guru hendaknya sering memberikan materi yang problematis untuk merangsang rasa ingin tahu peserta didik yang pada gilirannya akan membuat peserta didik aktif belajar.

8. Balikan dan penguatan. Dengan balikan peserta didik akan mengetahui sejauh mana kemampuannya dalam suatu hal, dimana letak kekuatan dan kelemahannya. Sedangkan penguatan (reinforcement) adalah suatu tindakan 
yang menyenangkan dari guru terhadap peserta didik yang telah berhasil melakukan suatu perbuatan belajar.

9. Perbedaan individual. Masing-masing peserta didik mempunyai karakteristik, baik dari segi psikis maupun fisik. Dengan adanya perbedaan ini tentu kemampuan minat serta kemampuan belajar mereka tidak persisi sama. Oleh karena itu guru tidak boleh menyamakan kondisinya seperti benda mati.

Berdasarkan latar belakang masalah yang telah diuraikan tersebut, penelitian ini bertujuan untuk menguji secara empiris hubungan kesiapan belajar terhadap kreativitas pengembangan media layanan bimbingan dan konseling pada mahasiswa program studi bimbingan dan konseling IKIP PGRI MADIUN.

\section{Metode Penelitian}

Penelitian ini menggunakan pendekatan kuantitatif-non eksperimental karena peneliti ingin memperoleh gambaran variabel penelitian tentang kreativitas pengembangan media bimbingan dan konseling ditinjau dari kesiapan belajar yang mengacu pada data-data yang telah dikumpulkan dan pengujiannya dengan metode statistik tanpa memberikan perlakuan.

Penelitian ini ditujukan untuk mengetahui hubungan suatu variabel dengan variabel lain. Hubungan antara satu variabel dengan beberapa variabel lain dinyatakan dengan besarnya koefisien korelasi dan keberartian (signifikansi) secara statistik (Sukmadinata, 2009).

Populasi dalam penelitian ini adalah mahasiswa program studi bimbingan dan konseling IKIP PGRI MADIUN semester 5 tahun akademik 2014/2015 yang sedang menempuh mata kuliah PPL BK Mikro. Mahasiswa tersebut sejumlah 125 orang. Sampel yang diambil dalam penelitian ini adalah 92 mahasiswa. Pengambilan sampel penelitian ini dilakukan secara acak (random).

Sukmadinata (2009) mengungkapkan tujuan utama pengambilan sampel secara acak (random) adalah dari sampel random dalam batas-batas tertentu dapat ditarik kesimpulan atau generalisasi yang berlaku bagi populasi. Pengambilan sampel secara random memungkinkan digunakan perhitungan statistik inferensial, sebagaimana perhitungan statistik yang digunakan dalam penelitian ini. 
Penggunaan statistik inferensial dapat memungkinkan peneliti membuat kesimpulan-kesimpulan tentang populasi berdasarkan perhitungan terhadap angka-angka yang diperoleh dari sampel. Tanpa pengambilan sampel secara random, sulit dapat menarik kesimpulan dari sampel.

Pengambilan sampel secara random menjadikan seluruh individu yang menjadi anggota populasi memiliki peluang yang sama dan bebas dipilih sebagai anggota sampel. Setiap individu memiliki peluang yang sama untuk diambil sebagai sampel, karena individu-individu tersebut memiliki karakteristik yang relatif sama. Sugiyono (2009) mengemukakan bahwa cara pengambilan sampel secara random tanpa mempertimbangkan strata yang ada dalam populasi dapat dilakukan jika anggota populasi dianggap homogen. Suryabrata (2003) menyatakan bahwa makin tinggi tingkat random dalam penentuan sampel, akan makin tinggi tingkat representatif sampelnya. Ketentuan teknik pengambilan sampel secara random hanya berlaku jika populasinya tidak homogen secara sempurna. Jika populasinya homogen secara sempurna, teknik random tidak diperlukan.

Pengambilan sampel dilakukan dengan melakukan undian kepada seluruh populasi sesuai dengan kelas masing-masing tanpa pengembalian sehingga diperoleh jumlah sampel sebanyak 92 mahasiswa. Berdasarkan penentuan ukuran sampel dengan menggunakan tabel Krejcie yang mendasarkan pengambilan subyek secara proporsional, sehingga untuk mencapai jumlah sampel sebanyak 92 mahasiswa dari 3 kelas, setiap kelas diambil 31 orang sebagai sampel.

Metode pengumpulan data pada penelitian ini menggunakan 2 macam skala, yaitu:

\section{Skala Kreativitas}

Skala ini disusun berdasarkan modifikasi terhadap skala C.O.R.E yang disusun oleh Suharnan (2011). Alat ukur ini dirancang untuk mengungkap potensi kreatif yang bersumber dari karakteristik kepribadian atau nonkognitif. Alat ukur ini menggunakan dasar teori Ayan (Suharnan, 2011) yang berpandangan bahwa selain komponen kognitif (kemampuan berpikir), juga kreativitas melibatkan komponen kepribadian seseorang. Adapun 
komponen kepribadian yang penting meliputi empat sifat, yaitu rasa ingin tahu, keterbukaan terhadap pengalaman dan informasi baru, toleransi terhadap resiko, dan energi (energi fisik dan energi mental).

2. Skala Kesiapan Belajar

Skala kesiapan belajar penyusunannya menggunakan butir-butir pernyataan jenis tertutup dan bersifat obyektif. Skala Likert digunakan sebagai bentuk respon responden terhadap pernyataan-pernyataan yang disusun. Penyusunan dan pengembangan butirnya didasarkan pada aspek (a) Kondisi fisik, mental dan emosional, (b) Kebutuhan-kebutuhan, motif dan tujuan, (c) Ketrampilan, pengetahuan dan pengertian yang lain yang telah dipelajari (Slameto, 2003:113).

Sebelum melakukan penelitian, terlebih dahulu dilakukan uji coba alat ukur dengan tujuan untuk mengetahui apakah alat ukur mampu menghasilkan data yang akurat sesuai dengan tujuan ukurnya. Data uji coba digunakan untuk menghitung daya beda aitem dan reliabilitas alat ukur.

Pengambilan data uji coba skala kreativitas dan skala kesiapan belajar dikenakan kepada 32 orang mahasiswa semester 5 tahun akademik 2014/2015 program studi bimbingan dan konseling IKIP PGRI MADIUN. Data yang diperoleh dari uji coba alat ukur akan diperoleh estimasi validitas datanya dengan menggunakan pengujian terhadap isi skala melalui analisis rasional dan estimasi reliabilitasnya menggunakan teknik koefisien reliabilitas Alpha Cronbach.

Hasil analisis reliabilitas yang dilakukan terhadap 24 aitem skala kreativitas, terdapat 19 aitem valid dan 5 aitem gugur dengan menggunakan koefisien korelasi aitem total untuk jumlah subyek 32 orang adalah 0,349 dan taraf signifikansi $5 \%$. Berdasarkan 19 aitem yang valid diperoleh koefisien korelasi aitem total terkoreksi berkisar antara 0,369-0,712. Hasil analisis reliabilitas menghasilkan koefisien Alpha sebesar 0,902.

Hasil analisis reliabilitas yang dilakukan terhadap 21 aitem skala kesiapan belajar, terdapat 16 aitem valid dan 5 aitem gugur dengan menggunakan koefisien korelasi aitem total untuk jumlah subyek 32 orang adalah 0,349 dan taraf signifikansi 5\%. Berdasarkan 19 aitem yang valid diperoleh koefisien korelasi 
aitem total terkoreksi berkisar antara 0,349-0,708. Hasil analisis reliabilitas menghasilkan koefisien Alpha sebesar 0,866.

\section{Hasil Penelitian}

Sebelum dianalisis, data yang diperoleh terlebih dahulu diuji asumsi yang meliputi uji normalitas dan uji linearitas. Uji normalitas diperlukan untuk mengetahui normal tidaknya sebaran skor skala kreativitas dan skala kesiapan belajar. Uji linearitas dilakukan untuk mendapatkan hubungan antara variabelvariabel yang ada, sedangkan uji homogenitas dilakukan untuk mengetahui apakah variasi dalam kelompok adalah sama.

Uji normalitas terhadap sebaran skor skala kreativitas diperoleh nilai Kolmogorov-Smirnov $\mathrm{Z}$ sebesar 0,611 dengan $\mathrm{p}=0,849$ ( $>0,05$; signifikan). Ini menunjukkan bahwa sebaran skor skala kreativitas pengembangan media layanan bimbingan dan konseling adalah normal. Hasil uji normalitas variabel kesiapan belajar diperoleh nilai Kolmogorof-Smirnov Z sebesar 0,611 dengan $p=0,849$ ( $>0,05$; signifikan). Ini menunjukkan bahwa sebaran skor skala kesiapan belajar adalah normal.

Hasil uji linearitas hubungan antara kreativitas pengembangan media layanan bimbingan dan konseling dengan kesiapan belajar diperoleh nilai $\mathrm{F}$ linear sebesar 6,159 dan signifikansi 0,015 ( $\mathrm{p}<0,05$; signifikan). Hasil tersebut menunjukkan bahwa hubungan antara kreativitas pengembangan media layanan bimbingan dan konseling dengan kesiapan belajar adalah linear.

Langkah selanjutnya adalah dilakukan uji hipotesis dengan menggunakan uji korelasi untuk mengetahui hubungan antar variabel. Berdasarkan uji korelasi diperoleh koefisien korelasi sebesar 0,253 dengan taraf signifikansi 0,015 ( $<<0,05$; signifikan). Hal ini menunjukkan ada hubungan positif yang signifikan antara kesiapan belajar dengan kreativitas pengembangan media layanan bimbingan dan konseling, artinya semakin tinggi kesiapan belajar maka semakin tinggi kreativitas pengembangan media layanan bimbingan dan konseling, dan sebaliknya semakin rendah kesiapan belajar maka semakin rendah kreativitas pengembangan media layanan bimbingan dan konseling. 
Hasil belajar dapat diraih jika mahasiswa mampu untuk bertanggung jawab terhadap amanat yang diembannya. Aplikasi dari tanggung jawab tersebut adalah terbentuknya individu yang rajin belajar dengan tekun serta mampu menjaga faktor internal dan eksternal yang mampu mempengaruhi hasil belajar, seperti, faktor kesehatan, intelegensi dan lain-lain (Antara, 2014). Individu yang mampu menunjukkan sikap seperti itu adalah individu yang memiliki kesiapan belajar. Kesiapan individu, termasuk mahasiswa akan membuat mahasiswa siap memberikan respon terhadap situasi yang dihadapi dengan caranya sendiri. Kesiapan adalah keseluruhan semua kondisi individu yang membuatnya siap untuk memberikan respon atau jawaban di dalam cara tertentu terhadap situasi tertentu. Kondisi tertentu yang dimaksud adalah kondisi fisik dan psikisnya, sehingga untuk mencapai tingkat kesiapan yang maksimal diperlukan kondisi fisik dan psikis yang saling menunjang kesiapan individu tersebut dalam proses pembelajaran (Slameto, 2010).

Melalui penelitiannya, Mulyani (2013) mengungkapkan bahwa kesiapan belajar meliputi 1) mempelajari catatan yang lalu; b) menyelesaikan tugas/latihan; c) menjaga kesehatan dan kebugaran fisik; d) membaca bahan yang akan dipelajari; e) membuat pertanyaan; dan f) menyiapkan perlengkapan belajar. Mahasiswa yang memiliki kesiapan belajar yang baik salah satu indikatornya akan menyiapkan perangkat belajarnya sebelum mengikuti proses pembelajaran. Jika dikaitkan dengan persiapan yang harus dilakukan oleh mahasiswa program studi bimbingan dan konseling yang sedang menempuh mata kuliah PPL BK Mikro, maka bisa diartikan mahasiswa yang memiliki kesiapan belajar yang baik maka akan menyiapkan Rencana Pelaksanaan Layanan Bimbingan dan Konseling (RPL-BK) yang akan dipraktikkan berserta dengan media layanan yang akan digunakan sebagai alat penunjang penyampaian materi.

Media bimbingan dan konseling yang dapat dikembangkan oleh mahasiswa diantaranya adalah slide power-point, tayangan video yang berkaitan dengan materi layanan, skenario drama untuk bermain peran, maupun media berupa papan bimbingan. Penggunaan media dalam proses pemberian layanan BK dapat bermanfaat untuk meningkatkan perhatian konseli pada saat mahasiswa 
(praktikan) menyampaikan materi layanan. Selain itu, juga dapat memudahkan mahasiswa dalam penyampaian materi layanan sehingga proses penyampaian materi tidak monoton dan tidak membosankan.

Dalam penyusunan media layanan bimbingan dan konseling dibutuhkan kreativitas mahasiswa. Untuk bisa mengembangkan kreatifitas, mahasiswa harus diberi kesempatan untuk menyampaikan pikiran atau pendapatnya mengenai sebuah ide tertentu. Selain itu mahasiswa harus diberi kesempatan untuk menuangkan imajinasinya dalam kesempatan atau tindakan tertentu (Wibowo, 2008). Dalam proses pembelajaran diperlukan cara yang mendorong mahasiswa untuk memahami masalah, meningkatkan kemampuan berpikir kreatif mahasiswa dalam menyusun rencana penyelesaian dan melibatkan mahasiswa secara aktif dalam menemukan sendiri penyelesaian masalah (Supardi, tth). Hal ini penting untuk dikembangkan karena mahasiswa prodi bimbingan dan konseling nantinya akan berperan menjadi guru di sekolah.

Uraian tersebut sejalan dengan hasil penelitian Sunaryo (2009) yang mengatakan bahwa Guru merupakan jabatan profesi yang memerlukan keahlian khusus sebagai guru. Dalam pelaksanaanya, guru dituntut memiliki berbagai keterampilan atau kreativitas mengajar, strategi belajar mengajar yang tepat, dan kemampuan melaksanakan evaluasi yang baik. Dengan wawasan yang luas diharapkan guru mampu memperhitungkan berbagai kemungkinan yang akan terjadi dengan pertimbangan kondisi sekarang dan pengalaman masa lalu. Tujuan ini adalah agar guru dapat memahami bahwa dalam melaksanakan fungsi dan perannya sebagai fasilitator pendidikan, guru diharapkan mempunyai kemampuan dan kreativitas dalam menjalankan kegiatan mengajar sebagai transforming science kepada siswa sebagai penerima dan pengembang ilmu yang telah diberikan oleh guru selama kegiatan pengajaran berlangsung di dalam kelas.

Hasil penelitian ini dapat disimpulkan bahwa ada hubungan antara kreativitas pengembangan media bimbingan dan konseling dengan kesiapan belajar mahasiswa program studi bimbingan dan konseling IKIP PGRI MADIUN. Guna meningkatkan kreativitas pengembangan media bimbingan dan konseling pada mahasiswa maka mahasiswa perlu didorong untuk meningkatkan kesiapan 
belajarnya, dengan cara menyiapkan perangkat belajar sebelum proses pembelajaran dimulai.

Daftar Pustaka

Antara, I.N.R., dkk. 2014. Pengaruh Kesiapan dan Transfer Belajar Terhadap Hasil Belajar Ekonomi di SMA Negeri I Ubud. Jurnal Pendidikan Ekonomi Universitas Pendidikan Ganesha. Vol. 4 No. 1 Tahun 2014

Arsyad, Azhar. 2011. Media Pembelajaran. Jakarta: PT Raja Grafindo Persada

Darsono, M. 2002. Belajar dan Pembelajaran. Semarang: IKIP Semarang Press

Djamarah, S.B. \& Zain, A. 2006. Strategi Belajar Mengajar. Jakarta: Rineka Cipta

Mulyani, D. 2013. Hubungan Kesiapan Belajar Siswa dengan Prestasi Belajar. Konselor. Jurnal Ilmiah Konseling. Vol. 2 No. 1 Januari 2013 Hal. 27 - 31

Munandar, U. 2009. Pengembangan Kreativitas Anak Berbakat. Jakarta: Rineka Cipta

Ormrod, J.E. 2009. Psikologi Pendidikan: Membantu Siswa Tumbuh dan Berkembang. Jakarta: Erlangga

Slameto. 2009. Belajar dan Faktor-faktor yang Mempengaruhinya. Jakarta: Rineka Cipta

Sugiyono. 2009. Metode Penelitian Pendidikan. Pendekatan Kuantitatif, Kualitatif dan $R \& D$. Bandung: Alfabeta

Suharnan. 2011. Kreativitas Teori dan Pengembangan. Surabaya: Laros

Sujiono,Bambang \& Yuliani Nurani Sujiono. 2005. Menu Pembelajaran Anak Usia Dini. Jakarta: Yayasan Citra Pendidikan Indonesia

Sukmadinata, N.S. 2009. Metode Penelitian Pendidikan. Bandung: PT. Remaja Rosdakarya

Sunaryo. 2009. Peningkatan Kemampuan dan Kreativitas Guru dalam Proses Kegiatan Belajar Mengajar di Kelas. Mimbar Pendidikan Universitas Pendidikan Indonesia. Nomor 2/XXVIII/2009

Supardi. th. Peran Berprikir Kreatif dalam Pembelajaran Matematika. Jurnal Formatif 2 (3): 248 - 262. Universitas Indraprasta PGRI

Suryabrata, S. 2003. Metodologi Penelitian. Jakarta: PT. RajaGrafindo Persada

Wibowo, S.M. 2008. Pengembangan Kreatifitas. Disampaikan dalam Semiloka Guru TK. Taruna Bakti Tanggal 23 Februari 2008 